\title{
Resolving tectono-magmatic processes that drive multi-Myr arc magma evolution in Central Chile
}

SIMON J. E. LARGE ${ }^{1}$, CHETAN NATHWANI ${ }^{1}$, YANNICK BURET $^{1}$, SIMON R TAPSTER ${ }^{2}$, TOM KNOTT ${ }^{3}$ AND JAMIE J WILKINSON $^{4,5}$

${ }^{1}$ Natural History Museum

${ }^{2}$ British Geological Survey

${ }^{3}$ University of Leicester

${ }^{4}$ Imperial College London

${ }^{5}$ The Natural History Museum

Presenting Author: s.large@nhm.ac.uk

Andean-style subduction zones produce a high variety of magma compositions over time and space. The diversity of magmas in these settings can be driven by the flux from the subducting slab, the melting behaviour of the overlying mantle wedge and crustal differentiation but the dominant process remains debated.

The Rio Blanco-Los Bronces district, $\sim 30 \mathrm{~km}$ northeast of Santiago in Central Chile, provides an ideal field location to examine the temporal evolution of an arc segment over several Myr. The Miocene San Francisco Batholith $(\sim 30$ x $20 \mathrm{~km})$ is intruded by porphyry intrusions of Late Miocene to Early Pliocene age. These porphyries form the Rio Blanco-Los Bronces Copper porphyry deposit cluster, and together with the San Francisco Batholith provide a near continuous igneous rock record over $>13 \mathrm{Myr}(\sim 17-4 \mathrm{Ma})$. Here, by combining wholerock geochemistry, isotopic tracing, LA-ICP-MS U-Pb zircon geochronology and petrological modelling we develop a temporally resolved geochemical data-set over the entire duration of batholith assembly and porphyry intrusion to examine the processes driving the changes in arc magma composition through time.

The protracted but incremental emplacement of magma batches building the San Francisco Batholith and the Rio BlancoLos Bronces porphyry intrusions is characterised by continuous trends in magmatic trace element signatures over time. The evolution of most elements can be accounted for by systematic changes in the lower crustal fractionation assemblage based on Monte Carlo modelling of Rayleigh fractionation scenarios. However, Rayleigh fractionation alone fails to account for systematic temporal shifts in $\mathrm{Ba} / \mathrm{Th}$ and $\mathrm{Th} / \mathrm{La}$. These require either variation in the source magma composition generated in the magma wedge or a significant change in the degree of assimilation or composition of the assimilant over time. Using isotopic evidence, we argue that all observed geochemical characteristics are best explained by the ingression of the Juan Fernandez ridge leading to a progressively deeper main locus of fractionation and assimilation. Our findings highlight the strong crustal control on arc magma compositions in subduction zone settings with thick continental crust. 